\title{
"Positioning firms in a new business performance space: an empirical study design on Euronext listed companies"
}

\author{
AUTHORS \\ Gianpaolo lazzolino iD https://orcid.org/0000-0001-9756-1223 \\ Giuseppe Migliano
}

Gianpaolo lazzolino and Giuseppe Migliano (2016). Positioning firms in a new

ARTICLE INFO

business performance space: an empirical study design on Euronext listed companies. Investment Management and Financial Innovations, 13(4), 106-119. doi:10.21511/imfi.13(4).2016.09

DOI http://dx.doi.org/10.21511/imfi.13(4).2016.09

RELEASED ON Thursday, 15 December 2016

JOURNAL "Investment Management and Financial Innovations"

FOUNDER LLC "Consulting Publishing Company "Business Perspectives"

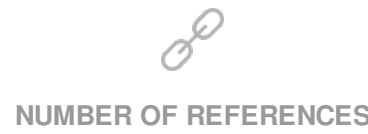

0
NUMBER OF FIGURES

0

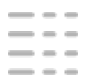

NUMBER OF TABLES

0

(C) The author(s) 2022. This publication is an open access article. 
Gianpaolo lazzolino (Italy), Giuseppe Migliano (Italy)

\title{
Positioning firms in a new business performance space: an empirical study design on Euronext listed companies
}

\begin{abstract}
Purpose - This research was designed to shed light on what is the role played by intellectual capital within firms for the achievement of leadership positions, according to two main perspectives: (i) intellectual capital commitment and (ii) financial/market performances.

Design/methodology/approach - An exploratory study design, involving 10-year data about 45 firms listed on Euronext 100, was devised. Firstly, firms were rated according to their intellectual capital commitment and their financial performances, by gathering indicators from a literature analysis; then, a new tool was developed the Positioning Matrix, which is a new business space, where firms can be placed according to the rates received in the first phase. Finally, the authors analyzed all the changes that the sample firms experienced all over the ten years considered.

Findings - Findings showed how companies can get the market leadership by using strategies based on their intellectual capital commitment. It was empirically found that intellectual capital should be considered as a necessary, but not sufficient condition to be recognized amongst the market leaders.

Research limitations/implications - The main limitation of this study is that it is based on an empirical standpoint; therefore, it could be interesting to verify the findings by using quantitative approaches. Since there are no standard ways to disclose intellectual capital information, some companies had to be excluded from analysis.

Originality/value - This work was especially designed for practitioners who could use the Positioning Matrix to (i) figure out how intellectual capital could contribute to get a better position within the market and (ii) have a better understanding of the investments into intellectual capital made by other firms (i.e., competitors, partners, etc.) to get the market leadership.
\end{abstract}

Keywords: intellectual capital; business performances; financial performance evaluation, Euronext.

JEL Classification: 034, L1.

\section{Introduction}

Intellectual Capital as "hidden value". During the last decades, the modern economy has been changing quickly due to the increasingly usage of knowledge-based resources that have revolutionized the way of competing in new marketplaces chiefly characterized by many threats (i.e., technological, financial, etc.) (Hsu and Sabherwal, 2011; Kamukama et al., 2011; Wang et al., 2014;Corvelo et al., 2013; Abhayawansa et al., 2015; Asiaei and Jusoh, 2015).

Following these new market changes, firm's market value cannot be evaluated taking into account only tangible resources, but even by adding the "intangible value" (Iazzolino et al., 2013a). To date, knowledge-based resources, represented by the intellectual capital resources, often "replace" the traditional ones: land, capital and work (Stewart, 1997; Sveiby, 1997; Bontis, 1999; Bounfour and Edvinsson, 2005; O’Donnell et al., 2006). However, as claimed by Chan et al. (2001) and Lev (2003), there are firms that are systematically undervalued within the markets where they operate in spite of investing endlessly in intellectual capital; this is chiefly due to a lack of understanding of the

\footnotetext{
(C) Gianpaolo Iazzolino, Giuseppe Migliano, 2016.

Gianpaolo Iazzolino, Dr., Dept. Mechanical, Energy and Management Engineering, University of Calabria, Italy.

Giuseppe Migliano, Dr., Dept. Mechanical, Energy and Management

Engineering, University of Calabria, Italy.
}

relationships existing between intellectual resources and firms' market performances, in fact, such kind of relations are often non-linear (Murthy and Mouritsen, 2011). Hence, to what concern these linkages, many authors have focused their attention on the asymmetry between the market and the book value stating that one of the main factors influencing firms' market value is the intellectual capital (Edvinsson, 1997; Sveiby, 1997; Lynn, 1998; Tseng et al., 2013); therefore, it has become interesting to study the relationship between it and market value.

Furthermore, although the crucial role of intellectual capital have been recognized by both scholars and practitioners as one of the most important drivers of firms' growth, value and financial success, companies need to face issues linked to the intellectual capital management practices mainly due to the difficulty of measuring it (Andrikopoulos, 2005; Kim and Kumar, 2009; Nazari and Herremans, 2007).

By looking the past literature, results of different analysis shed light on the fact that there is a "hidden value" that, though it cannot be easily gathered by observing only the financial statements, it is able to create competitive advantage, particularly for new dynamic markets (Chen et al., 2005; Edvinsson and Malone, 1997; Lev and Radhakrishnan, 2003; Lev and Zarowin, 1999; Lev, 2001; Ruta, 2009; Yang and Lin, 2009; Iazzolino et al., 2013a). 
Thus, the wide acceptance of the intellectual capital as a driver of competitive advantage leaded many authors to carry out methodologies that strove to measure this "hidden value", recognizing the fact that the traditional accounting and financial measures are not able to show it (Campisi and Costa, 2008; Nazari and Herremans, 2007; Curado et al., 2011), representing only a (tangible) part of the "real" firm's value. According to Firer and Williams (2003) and Chen et al. (2005), if a market is considered as efficient, investors ascribe a higher value to the firms (obviously operating in that market) having a high value of intellectual capital resources.

To conclude, this work aims to investigate how the intellectual capital helps firms to get the financial/market performance leadership by (i) harvesting 10-years data (from 2003 to 2012) on a sample made up by 45 companies listed on the Euronext stock exchange and (ii) developing a new tool for positioning these firms according to two main perspectives:

1. intellectual capital;

2. financial/market performances.

The main contribution related to this research is to provide analysts of a tool that is able to help them in (i) identifying strategies to be adopted to get a market leadership position taking into account not only financial performances, but also considering intellectual capital commitment; (ii) having a better understanding of the top-tier firms that lead the market by investing in their intellectual capital resources.

Thus, the paper is organized as follows: in its first part, literature regarding the intellectual capital (IC) is examined in order to constitute the conceptual base to define the IC variables to be used during the analysis; in the subsequent part, the research framework, results and discussions are displayed; finally, some conclusions and future works are presented.

\section{Theoretical background: intellectual capital and firms' performance}

Intellectual capital (IC) has been widely studied by many academics and practitioners who have acknowledged its great importance within the context of firms' performance evaluation (Alipour, 2012; Youndt et al., 2004; Stewart, 1997; Thurow, 1999; Petty and Guthrie, 2000; Bontis, 2001; Wang et al., 2014). Even though there are a lot definitions of IC, one of the most accepted divides it into three main components: (i) human capital (HC), (ii) structural capital (SC), and (iii) relational capital (SC) (Hsu and Sabherwal, 2011; Iazzolino et al., 2013b). The first one includes experience, knowledge, intellect, behavior, relationship, attitude and special skills of the personnel (Cohen and Kaimenakis, 2007; Schiuma et al., 2008; Han and Li, 2015; Asiaei and Jusoh, 2015). Structural capital consists of non-human storehouses of knowledge in organizations; it can be defined as a general system for solving problem and innovation ( $\mathrm{Chu}$ et al., 2006; Han and Li, 2015; Asiaei and Jusoh, 2015). The last one regards the value created through the relations amongst organizations, suppliers, customers, shareholders and other institutions and/or individuals (Grasenik and Low, 2004; Chu et al., 2006; Han and Li, 2015; Asiaei and Jusoh, 2015). Many approaches have been advanced, in the last few years, across several industries. Chen et al. (2005), Phusavat et al. (2011), Tan et al. (2007), Razafindrambinina and Anggreni (2011), Wang (2011), Alipour (2012), Maditinos et al. (2011), Joshi et al. (2013) developed frameworks to investigate the relationship between IC, using VAIC components (Pulic, 2000; Iazzolino and Laise, 2013; Iazzolino et al., 2014), and firms' performances (generally measured taking into account profitability and market-based indicators). Iazzolino et al. (2013a) carried out a study in which the Pulic's scheme was extended to the other components of value added to discriminate between knowledge and capital-intensive firms, and further, the relationship between intellectual capital efficiency (ICE) and firm's market value was studied. Other studies which do not use the Pulic's scheme were developed by Guo et al. (2012), who provided a framework in which the relationship between intellectual capital (in particular, R\&D expenditures) and financial performance of listed biotech firms were analyzed. Murthy and Mouritsen (2011) discussed how intellectual capital is related to human, organizational, relational and financial capital using a case study of a firm that invests in intellectual capital (divided in its three components). F-Jardón and Martos (2009) dealt with developing a framework for wood Argentine companies by using items related both to the three IC dimensions (human, structural and relational capital) and firms' performances (measured by: output, cash flows, profit, yield, market value, equity, competitive advantage, professionalism of the employees, productivity, reduction of costs, transference of new technologies and modernisation of the facility innovation capacities). Li and $\mathrm{Wu}$ (2004) used IC indicators such as employee skills, R\&D and advertisement expenses to measure the relationship between IC and firms' performances (measured by total profits). Mention and Bontis (2013) studied the gap existing among IC components and business performance (industry leadership, future outlook, net 
profit, liquidity ratio, ROE, banking income, costincome ratio, overall response to competition, success rate in new product/service launches, overall business performance and success) within banks of Luxemburg and Belgium. An interesting research was carried out by Tseng et al. (2013) who analyzed the role of business strategies on IC and financial performance taking account the effects of financial crisis. Thus, the authors found that: IC impacted significantly on both business strategies and financial performance; business strategies had partial mediating effects between IC and financial performance; business strategies had significant impact on financial performance.

In addition to these studies, Gosh and Wu (2007) investigated, by using an exploratory study, whether analysts took account of intellectual capital information when evaluating firms' performances; hence, they examined (i) financial analysts' recommendations considering some combinations of intellectual capital and financial performance levels and (ii) the role of financial and intellectual capital measures with different performance levels and holding periods (comparing short vs long terms) for making recommendations. To get their objectives, Gosh and Wu (2007) used financial and IC indicators such as market to book value, IT expense rate, information systems related to employee ratio, R\&D on sales, patents per employee and ROI.

Vergauwen et al. (2007) studied the relationship existing between the intellectual capital disclosures (ICDs) and the relative importance of intangible assets as firm value drivers. To evaluate this relationship, Vergauwen et al. (2007) used some IC proxies such as: personnel cost on revenues and revenues on full-time employees to measure $\mathrm{HC}$; $\mathrm{R} \& \mathrm{D}$ expenses on revenues and intellectual property on total assets to estimate SC; marketing-sellingdistribution expenditures on revenues, Herfindahl Index of Business Segments and Herfindahl Index of Geographic Segments to have an indication of SC.

In the same direction, Alwert et al. (2009) investigated how intellectual capital reports (IC Reports) of SMEs impact on the evaluation behavior of analysts. The authors argued that IC reports allow a more homogeneous rating assessment to be implemented.

Table 1 shows a summary containing the applications and the approaches used in the articles previously cited.

Table 1. Summary of IC and firms' performances evaluation approaches

\begin{tabular}{|c|c|}
\hline Authors & Approach \\
\hline $\begin{array}{l}\text { Chen et al. (2005), Phusavat et al. (2011), Tan et al. (2007), Razafindrambinina } \\
\text { and Anggreni (2011), Wang (2011), Alipour (2012), Maditinos et al. (2011), } \\
\text { Joshi et al. (2013), lazzolino and Laise (2013), lazzolino et al. (2013a), } \\
\text { lazzolino et al. (2014). }\end{array}$ & $\begin{array}{l}\text { VAIC and measure of performances mainly related to profitability and market } \\
\text { indexes (VAIC-based approaches). }\end{array}$ \\
\hline $\begin{array}{l}\text { Guo et al. (2012), Murthy and Mouritsen (2011), F-Jardón and Martos (2009), } \\
\text { Li and Wu (2004), } \\
\text { Mention and Bontis (2013), Gosh and Wu (2007), Vergauwen et al. (2007), } \\
\text { Alwert et al. (2009). }\end{array}$ & $\begin{array}{l}\text { IC components (human, structural and relational capital) and firms' } \\
\text { performance evaluations (profitability, market, productivity) indexes. }\end{array}$ \\
\hline
\end{tabular}

In conclusion, intellectual capital should be considered by scholars and practitioners in order to get a better, deeper and clearer firms' performances evaluation (Alwert et al., 2009; F-Jardón and Martos, 2009; Iazzolino et al., 2013a, b; Curado et al., 2011). Evaluations about firms' performances were conducted by using several methods; however, there are few approaches which tried to integrate the two main perspectives of these: (i) financial and (ii) intellectual capital-based (Iazzolino et al.2013c, Iazzolino et al., 2014).

Hence, in this study, due to the increasing importance of the intellectual capital (IC) in many competitive environments, the authors propose a new tool aiming at positioning companies on the basis of their intellectual capital investments (ICI) and financial/market performances; both perspectives are measured by using some proxies extracted by considering the theoretical background on these topics. Thus, this work aims to discover how the intellectual capital could lead firms to get the leadership in this new business space, which is made up of intellectual capital and financial/market performance axes.

\section{Research methodology design}

Given the objective of investigating how firms' performances could be re-interpreted by looking at two main perspectives, (i) intellectual capital and (ii) financial performances respectively (Iazzolino et al., 2014), an exploratory study design based on Euronext listed firms has been carried out by the authors. The main hypothesis on which this study was based is showed below: Hp.1. High intellectual capital investments will lead
companies to get the market leadership.

This sentence was split by the authors into the two following ones to be verified: 
Hp.2. Firms with relatively low financial performances can get the market leadership only if their intellectual capital commitment is sufficiently good.

Hp.3. Firms with relatively good financial performances will get the market leadership only by investing in intellectual capital.

2.1. Dataset. The sample used in this research is made up of 45 firms listed on Euronext stock exchange. In a first step, the choice was based on the value of the stock market index Euronext 100, which represents the 100 titles having the highest capitalisation and most actively negotiated on Euronext ${ }^{1}$. Therefore, ten-year data (from 2003 to
2012) have been harvested from the Thomson Reuters DATASTREAM database and firms' reports.

In conclusion, the sample consists of 45 firms belonging to six different industries as follow:

1. Energy and Chemicals Industry (11 firms);

2. Consumer Goods \& Retail Industry (11 firms);

3. Information and Communication Technology (5 firms);

4. Engineering and Aerospace \& Defense (9 firms);

5. Services marketing (2 firms);

6. Financial services (7 firms).

\begin{tabular}{|c|c|c|c|c|}
\hline \multicolumn{5}{|c|}{ Industry: Energy and Chemicals Industry } \\
\hline Shell & Total & EDF & Schneider Electric & ASML Holding \\
\hline Galp Energia & Sanofi & Air Liquide & Essilor & Legrande \\
\hline AkzoNobel & & & & \\
\hline \multicolumn{5}{|c|}{ Industry: Consumer Goods \& Retail Industry } \\
\hline Ab_Inbev & Heineken & L’Oréal & Unilever & Danone \\
\hline Kering & Carrefour & Ahold Kon. & Jéronimo Martins & Pernod Ricard \\
\hline LVMH & & & & \\
\hline \multicolumn{5}{|c|}{ Industry: ICT } \\
\hline Philips & France Télécom S.A. & Vivendi & Dassault Systèmes & Iliad \\
\hline \multicolumn{5}{|c|}{ Industry: Engineering and Aerospace \& Defense } \\
\hline EADS & Bureau Veritas & Vinci & Saint-Gobain S.A. & Lafarge \\
\hline Renault & ArcelorMittal & Michelin & Technip & \\
\hline \multicolumn{5}{|c|}{ Industry: General services \& Marketing } \\
\hline Publicis Groupe & Sodexo Alliance & & & \\
\hline \multicolumn{5}{|c|}{ Industry: Financial services } \\
\hline AXA & BNP Paribas & Crédit Agricole S.A. & ING Group & KBC \\
\hline Société Générale & & & & \\
\hline
\end{tabular}

2.2. Variables description ${ }^{1}$. In order to discover how intellectual capital can help companies to get the market leadership, thirteen variables have been defined by the authors according to the literature linked to intellectual capital and firms' performance evaluation (Guo et al., 2012; Murthy and Mouritsen, 2011; F-Jardón and Martos, 2009; Li and Wu, 2004; Mention and Bontis, 2013; Gosh and $\mathrm{Wu}, 2007$; Vergauwen et al., 2007; Haslam et al. 2013; Tseng et al., 2013). In particular, the variables chosen are described in Table 3 (see Appendix).

2.3. The new business performance space (Positioning Matrix). To investigate how intellectual capital helps companies to enhance their performances (by looking at both learning and

\footnotetext{
${ }^{1}$ Concerning the first step, some firms had to be deleted due to a lack of data (and also due to the fact that exists an absence of tools able to measure and report the Intellectual Capital within the traditional financial statements) for the period of which this research takes account; furthermore, some companies do not disclose reports about Intellectual Capital to not reveal strategic information that could favor their competitors.
}

growth and financial perspectives, citing the balanced scorecard approach), the authors developed the following methodological steps:

1. Intellectual capital commitment computing ${ }^{2}$ : firms were divided into quartiles according to their commitment on intellectual capital, thus, a rating ranging from 1 (the lowest commitment) to 4 (the highest commitment) was assigned to them $\left(4=1^{\text {st }}\right.$ quartile; $3=2^{\text {nd }}$ quartile; $2=3^{\text {rd }}$ quartile $; 1=4^{\text {th }}$ quartile).

2. Financial scores computing: similarly to the previous step, companies were evaluated according to their financial performances; hence, they were rated 1 if they belonged to the $4^{\text {th }}$ quartile, which means they had, in a certain financial year, the worst financial performances (compared to the other ones in the sample); by contrast, companies were rated 4

\footnotetext{
${ }^{2}$ In presence of missing data, for certain companies, it was assigned " 0 " as value of the specific IC proxy and " 1 " as score related to that proxy, since the authors interpreted the lack of IC information as a low intellectual capital commitment expressed by those firms that did not disclose their IC data.
} 
if they belonged to the $1^{\text {st }}$ quartile, which means they had, in a certain financial year, the best financial performances (with respect to the other ones in the sample).

3. Evaluation: an intellectual capital and a financial global score $^{3}$ were computed (for all the 10-year data) as average of the ratings obtained on each indicator (intellectual capital and financial ones, respectively);

$$
\begin{aligned}
& {\text { GlobalICscore }(\text { year } X)_{i}} \\
& =\operatorname{avg}\left(\text { score }_{i 1} ; \text { score }_{i 2} ; \ldots ; \text { score }_{i j} ; \ldots ; \text { score }_{i m}\right), \\
& i=1, \ldots, 45 \text { firmsand }=1, \ldots, 8 \text { ICproxies }
\end{aligned}
$$

\section{Globalfinancialscore $(\text { year } X)_{i}$} $=\operatorname{avg}\left(\right.$ score $_{i 1} ;$ score $_{i 2} ; \ldots ;$ score $_{i k} ; \ldots ;$ score $\left._{i n}\right)$, $i=1, \ldots, 45$ firmsand $=1, \ldots, 7$ financialratios

4. Positioning: On the basis of the global Intellectual Capital and financial scores, firms were positioned in a new visual tool/map, showing the business space where firms can be compared to each other, which is represented by the following matrix (named as "Positioning Matrix":

\begin{tabular}{c|c|c|}
\cline { 2 - 3 } Financial perfomance & $\begin{array}{c}\text { Market-based } \\
\text { companies }\end{array}$ & Leaders \\
\cline { 2 - 3 } & Bad performers & Visionaries \\
\cline { 2 - 2 } & \multicolumn{2}{|c|}{ Intellectual capital commitment }
\end{tabular}

Fig. 1. Positioning Matrix

The Positioning Matrix is a map aiming at providing a graphical competitive positioning of four kinds of firms on the basis of two main dimensions (see Appendix):

Intellectual capital commitment: based on intellectual capital proxies, it indicates the overall score (ranging from 1 to 4) describing the investments in intellectual capital (ICIs - intellectual capital investments) made by a certain company in a certain financial year.

Financial Performance: based on financial ratios proxies, it indicates the overall score (ranging from 1 to 4 ) describing the financial/market performance obtained by a certain company in a certain financial year.

Thus, as stated previously, firms could be empirically positioned/classified as:

1. Leaders: these companies are characterized by a strong position in the business space. They have even long-term roadmaps due to their investments in

\footnotetext{
${ }^{3}$ Intellectual capital and financial global scores were obtained by looking at the single rating assigned in the previous two methodological steps (1 and 2).
}

intellectual capital resources. Since they have both good financial/market and intellectual capital performances, it is likely that they will lead the market wherein they operate; in fact, leaders have both a strong focus on the future (demonstrated by their high intellectual capital investments) and a good financial/market performance at present (in the reference year).

2. Market-based companies: these companies are generally characterized by a good financial/market performance; as a consequence, financially, they are better positioned in the business space, better than visionaries. However, they show difficulties in communicating or delivering their vision for the future; this could be noticed by looking at their low intellectual capital investments that highlight how companies classified as "market-based" are generally more focused on a short-term roadmap chiefly based on financial results. Being focused on short-term strategies could be misleading for these firms and may lead them towards a myopic way, since they could not be able to adapt their market behaviors in response to innovations (i.e., new technologies, products, services, processes, etc.), which could threaten their actual business model, introduced by competitors, customers, suppliers, etc. Generally, these companies need to improve their intellectual capital investments, thus, passing from a short-term to a long-term view, to become as strong as Leaders.

3. Visionaries: these companies make investments to enhance their intellectual capital resources; however, they do not reach a leadership position, since they do not perform well in terms of financial/market ratios. Visionaries show a longterm roadmap emphasized by their high investments in Intellectual Capital; thus, they assume some risks even because financial returns are not guaranteed immediately. It is expected that they will get a more stable leadership position for the future if they make the right choices about intellectual capital investments; however, companies pursuing a visionary way will not be fully credited, if their investment actions do not generate a valuable contribution in terms of new technologies, products, services, processes, etc., for the market (in fact, by measuring the financial ratios, it is possible to figure out if their long-term investments are returning or not). Visionaries are different from Bad performers since the first take risks, such as investing in complex R\&D projects, to get a better financial performance "returned" from those risks.

4. Bad performers: these kinds of firms are characterized by the lowest intellectual capital investments (or even commitment) and the worst returns in terms of financial/market performances; 
consequently, it can be noted that they have neither a long-term view nor good financial performance in the reference year (at present). It is expected that they cannot get a leadership position immediately (from a reference year to the next one), thus, they should take actions towards either short-term (actions aimed at maximizing current income by preserving the firm's capital and providing daily liquidity) or long-term time horizons (actions aimed at investing the firm's capital to get future and stable returns).

The Positioning Matrix is a map aiming at providing a graphical competitive positioning of four kinds of firms on the basis of two main dimensions:

Intellectual capital commitment: based on intellectual capital proxies (displayed in, it indicates the overall score (ranging from 1 to 4 ) describing the investments in intellectual capital (ICIs - intellectual capital investments) made by a certain company in a certain financial year.

Financial performance: based on financial ratios proxies, it indicates the overall score (ranging from 1 to 4 ) describing the financial/market performance obtained by a certain company in a certain financial year.

Thus, as stated previously, firms could be empirically positioned/classified as:

5. Leaders: these companies are characterized by a strong position in the business space. They have even long-term roadmaps due to their investments in intellectual capital resources. Since they have both good financial/market and Intellectual Capital performances, it is likely that they will lead the market wherein they operate; in fact, leaders have both a strong focus on the future (demonstrated by their high intellectual capital investments) and a good financial/market performance at present (in the reference year).

6. Market-based companies: these companies are generally characterized by a good financial/market performance; as a consequence, financially, they are better positioned in the business space, better than visionaries. However, they show difficulties in communicating or delivering their vision for the future; this could be noticed by looking at their low intellectual capital investments that highlight how companies classified as "market-based" are generally more focused on a short-term roadmap chiefly based on financial results. Being focused on short-term strategies could be misleading for these firms and may lead them towards a myopic way, since they could not be able to adapt their market behaviors in response to innovations (i.e., new technologies, products, services, processes, etc.), which could threaten their actual business model, introduced by competitors, customers, suppliers, etc. Generally, these companies need to improve their intellectual capital investments, thus, passing from a short-term to a long-term view, to become as strong as Leaders.

7. Visionaries: these companies make investments to enhance their intellectual capital resources; however, they do not reach a leadership position, since they do not perform well in terms of financial/market ratios. Visionaries show a longterm roadmap emphasized by their high investments in intellectual capital; thus, they assume some risks even because financial returns are not guaranteed immediately. It is expected that they will get a more stable leadership position for the future, if they make the right choices about intellectual capital investments; however, companies pursuing a visionary way will not be fully credited, if their investment actions do not generate a valuable contribution in terms of new technologies, products, services, processes, etc., for the market (in fact, by measuring the financial ratios, it is possible to figure out if their long-term investments are returning or not). Visionaries are different from Bad performers, since the first take risks, such as investing in complex $R \& D$ projects, to get a better financial performance "returned" from those risks.

8. Bad performers: these kinds of firms are characterized by the lowest intellectual capital investments (or even commitment) and the worst returns in terms of financial/market performances; consequently, it can be noted that they have neither a long-term view nor good financial performance in the reference year (at present). It is expected that they cannot get a leadership position immediately (from a reference year to the next one), thus, they should take actions towards either short-term (actions aimed at maximizing current income by preserving the firm's capital and providing daily liquidity) or long-term time horizons (actions aimed at investing the firm's capital to get future and stable returns).

\section{Research findings}

As claimed previously, this study started evaluating firms on the basis of (i) their commitment in intellectual capital and (ii) their financial/market performances; thus, shows how intellectual capital commitment scores have been computed for a defined reference year (i.e., 2012) ${ }^{3}$.

\footnotetext{
3 It was provided an example of the global evaluation to show to the readers how the scores were obtained.
} 
A similar evaluation, dubbed as "Step 2 - Financial performance score computing" in the methodology, was carried out to assign a score aiming at synthesizing firms' financial/market performances; therefore, the following shows how financial/market ratings were computed in a reference financial year (i.e., 2012).

Computations regarding the intellectual capital commitment and the financial performances that firms obtained within the period 2003-2012 were followed by what the authors labelled "Evaluation" in the methodological steps. It aimed at assessing the overall scores obtained by each company in the two perspectives considered in this study: intellectual capital and financial/market, respectively. As done for the previous steps, the following summarizes the outcomes obtained in a sample year, 2012, by the analysis:

The last step, "Positioning", concerned the placement of each company in the business space made up by (i) intellectual capital commitment (xaxis) and (ii) financial/market performance (y-axis). Fig. 1 displays the Positioning Matrix for the sample year 2012.

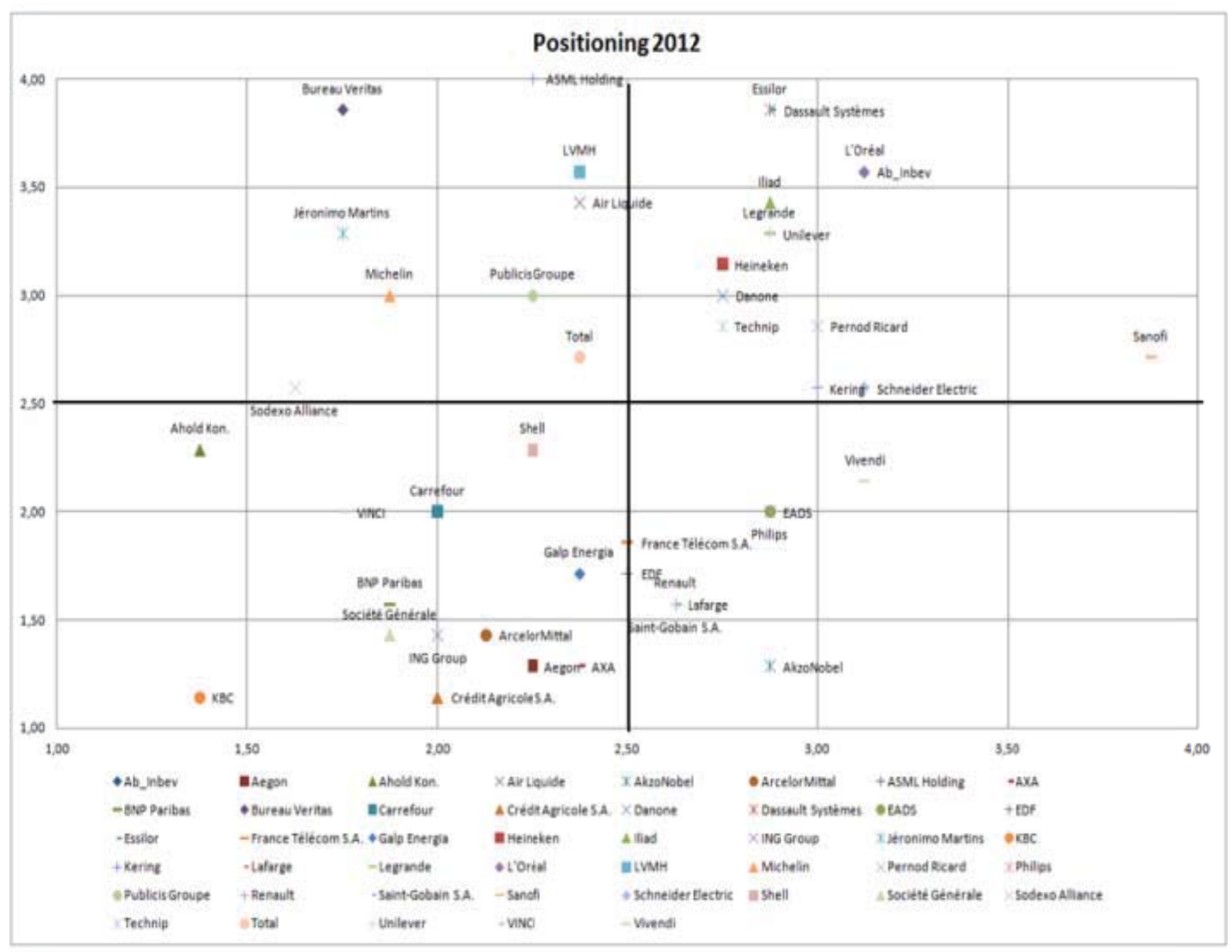

Fig. 1. Positioning Matrix (2012)

At the end of the analysis, the authors produced a table (Table 5) aiming at summarizing the results obtained for each financial year (from 2003 to 2012) taken into account, in order to help analysts to identify how companies move within the four quadrants of the business space described previously. Hence, by using this table, it is possible to have an idea on what strategies each company was focused over ten years.

\section{Discussions}

This work showed how firms' intellectual capital and financial/market performances can be viewed as two integrated perspectives (Iazzolino et al., 2014); particularly, it highlighted how firms can be positioned in a new business space made up by the perspectives beforehand mentioned.

Hence, starting from the Table 5 and the Positioning Matrixes (Fig. 1), it could be noticed (i) how the 45 firms of the sample performed over ten years and (ii) what position, amidst the four possible ones, they got within the business space from 2003 to 2012.

As claimed previously by looking at Table 5, it could be noted that firms did not have the same positioning throughout the considered period; therefore, the following Fig. 2 shows what changes occurred over all the ten years. 


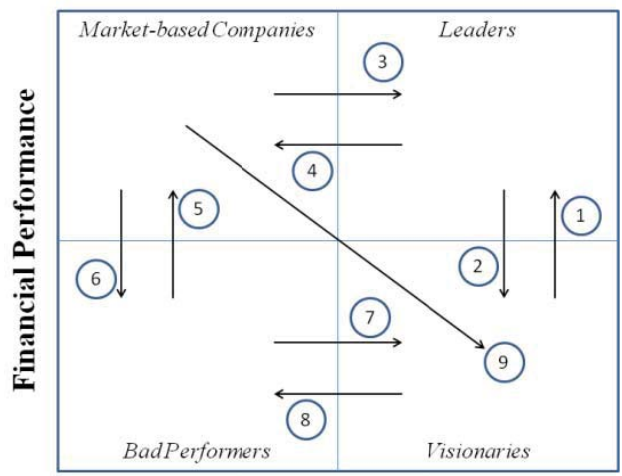

Intellectual Capital Commitment

n.tg. a. A vonumung unanger

This empirical study showed how firms can be positioned, and consequently, how they could get the market leadership, over their life (this work analyzed 10-year data for 45 companies) according to the integration of two main perspectives characterizing their overall performance: (i) intellectual capital commitment and (ii) financial/market results.

In their main hypothesis, the authors stated that intellectual capital investments help firms to get a leadership position; then, this main hypothesis was split into two where the authors claimed that the market leadership could be obtained even by firms having low financial performances, but that they are willing to invest steadily in intellectual capital $(\mathrm{Hp}$. 1) and that the market leadership could be reached by firms having good financial performances, only if they demonstrate to invest in intellectual capital (Hp. 2).

Starting from the Hp. 1 , it seems to be verified by the following changes (Fig. 2):

- Change 1 (Visionaries $\rightarrow$ Leaders): as stated previously, Visionaries are companies characterized by low financial/market results and high intellectual capital commitment. It is noteworthy that the majority of these firms (except one - AXA, which it is referred to change 8) became Leaders; thus, this could be intended as an empirical proof ${ }^{4}$ of what the authors stated in the Hp. 1 .

- Change 5 (Bad Performers $\rightarrow$ Market-based): this case is another confirmation of the Hp. 1 ; in fact, by looking at Table 5, it could be noticed that there are no Bad performers that got the market leadership directly. However, in this case, firms that experienced this change were able to get good financial performance, generally for short time frames.
- Change 7 (Bad Performers $\rightarrow$ Visionaries): it is similar to the previous case; in fact, Bad performers might decide to implement shortterm or long-term strategies; here, they start employing the second ones, however, a stable market leadership was not spotted, since, as beforehand claimed, it is quite improbable that stakeholders are able to recognize immediately the effort made by Bad performers for investing in intellectual capital resources.

Even the Hp. 2 seems to be verified by the findings (Table 5) and the changes displayed in Fig. 2:

- Change 3 (Market-based $\rightarrow$ Leaders): although Market-based companies have good financial performances, they are more focused on shortterm strategies; hence, they do not invest in intellectual capital, however, when passing to long-term roadmaps, Market-based companies demonstrated that they can get the market leadership in many cases (as demonstrated by Table 5). This kind of change could be considered as an empirical proof of what the authors stated in the Hp. 2 since firms having good financial performances can become Leaders only by investing in intellectual capital, which means they are implementing long-term strategic choices; in fact, in many cases, firms that experienced this change were able to maintain the leadership for more than two years.

- Change 9 (Market-based $\rightarrow$ Visionaries): this change is not a direct proof of the Hp. 2; however, it could be considered as an indirect empirical verification of it. By taking a look at Table 5, it might be noticed that Heineken passed from being a Market-based (2007) to being a Visionary (2008), after experiencing this change, it was acknowledged amidst Leaders since 2009. This could means that Heineken changed its strategy, from a short to a long-term one; although its effort was not recognized by the market immediately, its investments were awarded in the following years (from 2009 to 2012) and the company got a stable market leadership position. In conclusion, this change appeared in the analysis could be "mutated" into: Market-based $\rightarrow$ Visionaries $\rightarrow$ Leaders.

Summarizing, Hp. 1 and Hp. 2 (and, as a consequence, the main $\mathrm{Hp}$.) were verified by the analyses carried out in this empirical study; however, apart from those just mentioned, what did the other changes prove?

Changes 2, 4, 6 and 8 made clear (in this study) that:

\footnotetext{
${ }^{4}$ Empirical proof is intended to be limited to this specific sample
} 
Intellectual capital commitment is just a necessary, but not sufficient condition for a company to get the market leadership 5 .

In fact, although it has been widely recognized that intellectual capital influence financial/market performances (Guo et al., 2012; Murthy and Mouritsen, 2011; F-Jardón and Martos, 2009; Li and $\mathrm{Wu}, 2004$; Mention and Bontis, 2013; Gosh and Wu, 2007; Vergauwen et al., 2007; Alwert et al., 2009), these latter could be even affected by other factors such as, for instance, outsourcing strategies, amounts of liquidity and debts, stock price fluctuations, inflation, variations of the interest rates, etc. (Haslam et al., 2013; Damodaran, 2010; Venanzi 2012); therefore, this confirms that intellectual capital can play an important role for every company that struggles for achieving the market leadership (as explained by changes 1, 3, 5, 7, and 9), however, other factors, such those ones beforehand cited, could restrain the impact of intellectual capital investments (as borne out by changes 2, 4, 6 and 8).

\section{Conclusions}

This study drew up an empirical analysis to investigate how intellectual capital helps firms to get the market leadership.

The idea on which this work was devised, started considering that intellectual capital is a fundamental asset to get competitive advantage and, therefore, to compete globally in every market (Guo et al., 2012; Murthy and Mouritsen, 2011; F-Jardón and Martos, 2009; Li and $\mathrm{Wu}, 2004$; Mention and Bontis, 2013; Gosh and Wu, 2007; Vergauwen et al., 2007; Alwert et al., 2009; Corvelo et al., 2013; Iazzolino et al., 2013b; Abhayawansa et al., 2015).

In this research, a new tool has been developed, named as "Positioning Matrix", which aimed at positioning companies on the basis of (i) their intellectual capital commitment and (ii) financial/market performances; this could be useful, on the one hand, for scholars, to advance knowledge about the linkage between intellectual capital and financial theories; on the other hand, for practitioners, to figure out how investments in intellectual capital should be addressed to get, firstly, a better financial performances and, then, a stable leadership position in the markets in which they operate.

Despite these benefits, some research limitations are listed below:

- It should be considered a larger sample; in fact, such results are referred to only 45 firms (since there is not any standard way to disclose IC data, some companies needed to be excluded from the analysis);

- Hypotheses were investigated only empirically; therefore, it could be interesting to carry out and apply statistical and mathematical frameworks to verify them.

Therefore, further studies could be carried out taking account of these limitations and, then, they should consider a larger sample and also indicators not included in this analysis, such as investments plans in human capital (i.e., investment plans for employees), customer service expenses, customer satisfaction indexes, etc., which can be obtained by examining reporting documents drawn up by firms.

It should be investigated what external factors could be included within the Positioning Matrix, in order to provide guidelines to the firms and help them to increase their value. Furthermore, other quantitative methodologies and tools to evaluate intellectual capital, based, as previously stated, i.e., on statistical and mathematical approaches, need to be developed to get over limitations linked to empirical studies.

In conclusion, it could be argued that this research sheds light on implications that intellectual capital components could have on the achievement of the market leadership; firms should pay more attention to the development of their intellectual assets, as well as to their reporting system to have a clearer vision of its intangible assets on which they should be focused to get competitive advantage in this knowledge era.

\section{References}

1. Abhayawansa, S., Aleksanyan, M. and Bahtsevanoglou, J. (2015). The use of intellectual capital information by sell-side analysts in company valuation, Accounting and Business Research, Vol. 45, No. 3, pp. 279-306.

2. Alipour, M. (2012). The effect of intellectual capital on firm performance: an investigation of Iran insurance companies, Measuring Business Excellence, Vol. 16, No. 1, pp. 53-66.

3. Alwert, K., Bornemann, M. and Will, M. (2009). Does intellectual capital reporting matter to financial analysts? Journal of Intellectual Capital, Vol. 10, No. 3, pp. 354-368.

4. Andrikopoulos, A. (2005). The real-options approach to intellectual capital analysis: a critique, Knowledge and Process Management, Vol. 12, No. 3, pp. 217-224.

\footnotetext{
${ }^{5}$ As defined by the Positioning Matrix
} 
5. Asiaei, K. and Jusoh, R. (2015). A multidimensional view of intellectual capital: the impact on organizational performance, Management Decision, Vol. 53, No. 3, pp. 668-697.

6. Bontis, N. (1998). Intellectual capital: an exploratory study that develops measures and models", Management Decision, Vol. 36, No. 2, pp. 63-76.

7. Bontis, N. (1999). Managing Organizational Knowledge by Diagnosing Intellectual Capital: Framing and Advancing the State of the Field, International Journal of Technology Management, Vol. 18, No. 5-8, pp. 433-462.

8. Bontis, N. (2001). Assessing knowledge assets: a review of the models used to measure intellectual capital, International Journal of Technology Management, Vol. 3, No. 1, pp. 41-60.

9. Bontis, N., Keow, W.C.C. and Richardson, S. (2000). Intellectual capital and business performance in Malaysian industries, Journal of Intellectual Capital, Vol. 1, No. 1, pp. 85-100.

10. Bounfour, A. and Edvinsson, L. (2005). A public policy perspective on Intellectual Capital. In Marr, B. (Ed.), Perspectives on Intellectual Capital, Butterworth-Heinemann, Burlington, pp. 170-182.

11. Cabrita, M. and Bontis, N. (2008). Intellectual capital and business performance in the Portuguese banking industry, International Journal of Technology Management, Vol. 43, Nos. 1-3, pp. 212-237.

12. Calabrese, A. (2012). Service Productivity and Service Quality: A necessary trade-off? International Journal of Production Economics, Vol. 135, pp. 800-812.

13. Calabrese, A. and Scoglio, F. (2012). Reframing the past: A new approach in service quality assessment, Total Quality Management \& Business Excellence, Vol. 23, Nos. 11-12, pp. 1329-1343.

14. Campisi, D. and Costa, R. (2008). A DEA-based method to enhance intellectual capital management, Knowledge and Process Management, Vol. 15, No. 3, pp. 170-183.

15. Chan, L.K.C., Lakonishok, J. and Sougiannis, T. (2001). The stock market valuation of research and development expenditures, Journal of Finance, Vol. 56, No. 6, pp. 2431-2456.

16. Chen, M.C., Cheng, S.J. and Hwang, Y. (2005). An empirical investigation of the relationship between Intellectual Capital and firms' Market Value and financial performance, Journal of Intellectual Capital, Vol. 6, No. 2, pp. $159-176$.

17. Chen, S.S., Ho, K.W., Lee, C.F. and Yeo, G.H.H. (2000). Investment Opportunities Free Cash Flow and Market Reaction to International Joint Ventures, Journal of Banking \& Finance, Vol. 24, pp. 1747-1765.

18. Chu, P.Y., Lin, Y.L., Hsiung, H.H. and Liu, T.Y. (2006). Intellectual capital: an empirical study of ITRI, Technological Forecasting \& Social Change, Vol. 73, pp. 886-902.

19. Cohen, S. and Kaimenakis, N. (2007). Intellectual capital and corporate performance in knowledge-intensive SMEs, The Learning Organization, Vol. 14, No. 3, pp. 241-262.

20. Curado, C., Henriques, L. and Bontis, N. (2011). Intellectual capital disclosure payback, Management Decision, Vol. 49, No. 7, pp. 1080-1098.

21. Edvinsson, L. (1997). Developing Intellectual Capital at Skandia, Long Range Planning, Vol. 30, No 3, pp.366-373.

22. Edvinsson, L. and Malone, M.S. (1997). Intellectual capital: Realizing your company's true value by finding its hidden brainpower. Harper Business, New York, NY.

23. F-Jardón, C.M. and Martos, M.S. (2009). Intellectual capital and performance in wood industries of Argentina, Journal of Intellectual Capital, Vol. 10, No. 4, pp. 600-616.

24. Gosh, D. and Wu, A. (2007). Intellectual capital and capital markets: Additional evidences, Journal of Intellectual Capital, Vol. 8, No. 2, pp. 216-235.

25. Grasenick, K. and Low, J. (2004). Shaken, not stirred: defining and connecting indicators for the measurement and valuation of intangibles, Journal of Intellectual Capital, Vol. 5, No. 2, pp. 268-81.

26. Guo, W.C., Shiah-Hou, S.R. and Chien, W.R. (2012). A study on intellectual capital and firm performance in biotech companies, Applied Economics Letters, Vol. 19, No. 16, pp. 1603-1608.

27. Han, Y. and Li, D. (2015). Effects of intellectual capital on innovative performance: The role of knowledge-based dynamic capabilities, Management Decision, Vol. 53, No. 1, pp. 40-56.

28. Haslam, C.J., Anderson, T., Tsitsianis, N. and Ping Yin, Y. (2013). Apple's financial success: The precariousness of power exercised in global value chains, Accounting Forum, Vol. 37, No. 4, pp. 268-279.

29. Hsu, I-C. and Sabherwal, R. (2011). From Intellectual Capital to Firm Performance: The Mediating Role of Knowledge Management Capabilities, IEEE TRANSACTIONS ON ENGINEERING MANAGEMENT, Vol. 58, No. 4, pp. 626-642.

30. Iazzolino G. and Laise D. (2013). Value Added Intellectual Coefficient (VAIC): a methodological and critical review, Journal of Intellectual Capital, Vol. 14, No. 4, pp. 547-563.

31. Iazzolino, G., Laise, D. and Migliano, G. (2014). Measuring value creation: VAIC and EVA, Measuring Business Excellence, Vol. 18, No. 1, pp. 8-21.

32. Iazzolino, G., Migliano, G. and Gregorace, E. (2013a). Evaluating intellectual capital for supporting credit risk assessment: an empirical study, Investment Management and Financial Innovations, Vol. 10, No. 2, pp. 44-54.

33. Iazzolino, G., Migliano, G., Forgione, R. and Girimonte, M. (2013b). Capital efficiency and market value in knowledge and capital intensive firms: an empirical study, Investment Management and Financial Innovations, Vol.10, No. 2, pp. 147-157.

34. Iazzolino, G., Bruni, M.E. and Beraldi, P. (2013c).Using DEA and financial ratings for credit risk evaluation: an 
empirical analysis, Applied Economics Letters, Vol. 20, No. 14, pp. 1310-1317.

35. Joshi, M., Cahill, D. and Sidhu, J. (2013). Intellectual capital and financial performance: an evaluation of the Australian financial sector", Journal of Intellectual Capital, Vol. 14, No. 2, pp. 264-285.

36. Kamukama, N., Ahiauzu, A. and Ntayi, J.M. (2011). Competitive advantage: mediator of intellectual capital and performance, Journal of Intellectual Capital, Vol. 12 No. 1, pp. 152-164.

37. Kim, D.Y. and Kumar, V. (2009), "A framework for prioritization of intellectual capital indicators in R\&D”,Journal of Intellectual Capital, Vol. 10 No. 2, pp. 277-293.

38. Lev, B. and Zarowin, P. (1999). The boundaries of financial reporting and how to extend them, Journal of Accounting Research, Vol. 37, pp. 353-385.

39. Lev, B. (2003). The measurement, valuation and reporting of intangible assets, Federal Reserve Bank of New York Economic Policy Review, Vol. 9, No. 3, pp. 17-22.

40. Li, D.Q. and Wu, X.B. (2004). Empirical study on the linkage of Intellectual Capital and firm Performance, in Proceedings of IEEE International Enginering Management Conference, Singapore, Republic of Singapore, pp. 515-518.

41. Lynn, B.E. (1998). Performance evaluation in the new economy: bringing the measurement and evaluation of intellectual capital into the management planning and control system, International Journal of Technology Management, Vol. 16, Nos. 1-3, pp. 162-176.

42. Maditinos, D., Chatzoudes, D., Tsairidis, C. and Theriou, G. (2011). The impact of Intellectual Capital on firms' Market Value and financial performance, Journal of Intellectual Capital, Vol. 12, No. 1, pp. 132-151.

43. Mention, A.-L. and Bontis, N. (2013). Intellectual capital and performance within the banking sector of Luxembourg and Belgium, Journal of Intellectual Capital, Vol. 14, No. 2, pp. 286-309.

44. Murthy, V. and Mouritsen, J. (2011). The performance of intellectual capital Mobilising relationships between intellectual and financial capital in a bank, Accounting, Auditing \& Accountability Journal, Vol. 24, No. 5, pp. 622-646.

45. Nazari, J.A. and Herremans, I.M. (2007). Extended VAIC model: measuring intellectual capital components, Journal of Intellectual Capital, Vol. 8, No. 4, pp. 595-609.

46. O'Donnell, D., Tracey, M., Henriksen, L.B., Bontis, N., Cleary, P., Kennedy, T. and O'Regan, P. (2006). On the 'essential condition' of intellectual capital: labor!,Journal of Intellectual Capital, Vol. 7, No. 1, pp. 111-128.

47. Petty, R. and Guthrie, J. (2000). Intellectual capital literature review: measurement, reporting and management, Journal of Intellectual Capital, Vol. 1, No. 2, pp. 155-176.

48. Phusavat, K., Comepa, N., Sitko-Lutek, A. and Ooi, K.-B. (2011). Interrelationships between intellectual capital and performance Empirical examination, Industrial Management \& Data Systems, Vol. 111, No. 6, pp. 810-829.

49. Pulic, A. (2000). VAIC ${ }^{\mathrm{TM}}$ - an accounting tool for IC management, International Journal of Technology Management, Vol. 20, No. 5-8, pp. 702-714.

50. Razafindrambinina, D. and Anggreni, T. (2011). Intellectual Capital and Corporate Financial Performance of Selected Listed Companies in Indonesia, Malaysian Journal of Economic Studies, Vol. 48, No. 1, pp. 61-77.

51. Schiuma, G., Lerro, A. and Sanitate, D. (2008). The intellectual capital dimensions of Ducati's turnaround: exploring knowledge assets grounding a change management program, International Journal of Innovation Management, Vol. 12, No. 2, pp. 161-193.

52. Stewart, T.A. (1997). Intellectual Capital: The New Wealth of Organizations, Doubleday, New York, NY.

53. Sveiby, K.E. (1997). The new organizational wealth: managing \& measuring knowledge-based assets, BerrettKoehler, San Francisco, CA.

54. Tan, H.P., Plowman, D. and Hancock, P. (2007). Intellectual capital and financial returns of companies, Journal of Intellectual Capital, Vol. 8, No. 1, pp. 76-95.

55. Thurow, L.C. (1999). Building Wealth: the new rules for individuals, companies, and Nation in a knowledgebased economic, HarperCollins, New York, NY.

56. Tseng, K.-A., Lan, Y.-W., Lu, H.-C. and Chen, P.-Y- (2013). Mediation of strategy on intellectual capital and performance, Management Decision, Vol. 51, No. 7, pp. 1488-1509.

57. Vergauwen, P., Bollen, L. and Oirbans, E. (2007). Intellectual Capital Disclosure and Intangible Value Drivers: An Empirical Study, Management Decision, Vol. 45, No. 7, pp. 1163-1180.

58. Wang, M. (2011). Measuring intellectual capital and its effect on financial performance: evidence from the capital market in Taiwan, Frontiers of Business Research in China, Vol. 5, No. 2, pp. 243-265.

59. Wang, Z., Wang, N. and Liang, H. (2014). Knowledge sharing, intellectual capital and firm performance, Management Decision, Vol. 52, No. 2, pp. 230-258.

60. Yang, C.C. and Lin, C.Y.Y. (2009). Does intellectual capital mediate the relationship between HRM and organizational performance? Perspective of a healthcare industry in Taiwan, International Journal of Human Resource Management, Vol. 20, No. 9, pp. 1965-1984.

61. Youndt, M., Subramaniam, M. and Snell, S. (2004). Intellectual capital profiles: an examination of investment and returns, Journal of Management Studies, Vol. 41, No. 2, pp. 335-361. 


\section{Appendix}

Table 2. Intellectual capital and financial variables

\begin{tabular}{|c|c|c|}
\hline $\begin{array}{l}\text { Macro- } \\
\text { variable }\end{array}$ & Variable & Description \\
\hline \multirow{3}{*}{$\begin{array}{l}\text { Human } \\
\text { capital }\end{array}$} & $\begin{array}{l}\text { R\&D / No. } \\
\text { Employees }\end{array}$ & $\begin{array}{l}\text { It is the expression of the R\&D cost associated to each employee. This ratio makes possible to evaluate the impact of R\&D } \\
\text { activities on a single employee, assuming that each of them is involved in that those activities. }\end{array}$ \\
\hline & $\begin{array}{l}\text { Labour cost / } \\
\text { Sales }\end{array}$ & $\begin{array}{l}\text { It shows the percentage of sales invested in human capital. It could be interpreted as the company interest in investing in its } \\
\text { employees. }\end{array}$ \\
\hline & $\begin{array}{l}\text { Intangible assets } \\
\text { / No. Employees }\end{array}$ & $\begin{array}{l}\text { It is the expression of intangible assets associated to each employee. This ratio makes possible to evaluate how } \\
\text { investments in intangibles impact on a single employee. }\end{array}$ \\
\hline \multirow[b]{2}{*}{$\begin{array}{l}\text { Structural } \\
\text { capital }\end{array}$} & $\begin{array}{l}\text { Intangible assets } \\
\text { / Total assets }\end{array}$ & $\begin{array}{l}\text { It is the percentage of the intangible assets available in a certain organization. Intangibles are made up of resources often } \\
\text { classified as intellectual property resources like patents, marks, copyrights, brands, etc. A high value of this ratio means } \\
\text { there is a high structural capital within an organisation. }\end{array}$ \\
\hline & R\&D / Sales & $\begin{array}{l}\text { It represents the quantity of sales invested in R\&D activities (percentage of sales invested in R\&D). This ratio depends not } \\
\text { only by the will of an organization to invest in R\&D, but also by the industry in which an organization operates and by the } \\
\text { technological advancement of that sector (i.e., pharmaceutical companies generally have a higher value for this ratio due to } \\
\text { the high technological advancements in the sector in which they compete). Thus, there is a linkage between R\&D and } \\
\text { economic growth in spite of problems arisen for evaluating it. }\end{array}$ \\
\hline $\begin{array}{l}\text { Relational } \\
\text { capital }\end{array}$ & $\begin{array}{l}\text { Marketing \& } \\
\text { distribution } \\
\text { expenses / Sales }\end{array}$ & $\begin{array}{l}\text { It is the percentage of sales invested in marketing and distribution strategies. High investments in marketing and distribution } \\
\text { could be interpreted as a measure to express relationships existing between the organisation and its customers. }\end{array}$ \\
\hline \multirow{4}{*}{$\begin{array}{l}\text { Firm's } \\
\text { performance }\end{array}$} & EBITDA / Sales & It is a profitability index that represents the percentage of EBITDA generated by the sales. \\
\hline & $\begin{array}{l}\text { Cash ROCE }= \\
\text { EBITDA / Capital } \\
\text { employed } 1\end{array}$ & $\begin{array}{l}\text { It is the percentage of EBITDA generated by the investments made by an organization. This indicator is useful to identify } \\
\text { companies having high growth capacities. It is one of the most important financial performance measure as stated by } \\
\text { Haslam et al. (2013) }\end{array}$ \\
\hline & ROE & $\begin{array}{l}\text { ROE measures the income available to common stockholders as a percentage of the book value of their investment in the } \\
\text { organization. }\end{array}$ \\
\hline & $\mathrm{ROA}$ & ROA measures the organization's ability to use its assets to create profits \\
\hline \multirow{3}{*}{ Firm value } & $\begin{array}{l}\text { Market to Book } \\
\text { ratio }=\text { MV } / \text { BV }\end{array}$ & $\begin{array}{l}\text { It is used to investigate the gap existing between MV, calculated as share price * number of shares, and the BV (net book } \\
\text { value of assets - net book value of liabilities). The concept underlying this ratio is that the gap between MV and BV is due to } \\
\text { the "real" value of intangible resources. }\end{array}$ \\
\hline & MV / EBITDA & $\begin{array}{l}\text { It is a market multiple referring to the incomes. It represents the market value (MV) generated by the companies operating } \\
\text { margins/incomes. }\end{array}$ \\
\hline & MV / Sales & It is a market multiple that represents the market value generated by the Sales. \\
\hline
\end{tabular}

Table 3. Intellectual capital commitment scores (2012)

\begin{tabular}{|l|c|c|c|c|c|c|c|c|c|c|c|c|}
\hline \multicolumn{1}{|c|}{ Firm } & $\begin{array}{c}\text { LC/ } \\
\text { SALES }\end{array}$ & Score & $\begin{array}{c}\text { R\&D/ } \\
\text { NE }\end{array}$ & Score & $\begin{array}{c}\text { R\&D/ } \\
\text { SALES }\end{array}$ & Score & IA/TA & Score & IA/NE & Score & $\begin{array}{c}\text { M\&DE/ } \\
\text { Sales }\end{array}$ & Score \\
\hline Ab_Inbev & 0.121 & 1 & 1.199 & 3 & 0.005 & 3 & 0.625 & 4 & 490.613 & 4 & 0.271 & 4 \\
\hline Aegon & 0.068 & 1 & 0.000 & 1 & 0.000 & 1 & 0.003 & 1 & 44.577 & 2 & 0.190 & 3 \\
\hline Ahold Kon. & 0.136 & 2 & 0.000 & 1 & 0.000 & 1 & 0.107 & 2 & 12.552 & 1 & 0.020 & 2 \\
\hline Air Liquide & 0.174 & 3 & 3.794 & 3 & 0.012 & 3 & 0.238 & 2 & 118.368 & 3 & 0.000 & 1 \\
\hline AkzoNobel & 0.199 & 3 & 7.133 & 4 & 0.023 & 3 & 0.260 & 2 & 88.006 & 2 & 0.241 & 4 \\
\hline ArcelorMittal & 0.148 & 2 & 0.902 & 3 & 0.003 & 3 & 0.090 & 2 & 29.656 & 1 & 0.109 & 3 \\
\hline ASML Holding & 0.177 & 3 & 67.481 & 4 & 0.121 & 4 & 0.022 & 1 & 18.726 & 1 & 0.036 & 2 \\
\hline AXA & 0.072 & 1 & 0.000 & 1 & 0.000 & 1 & 0.026 & 1 & 202.439 & 4 & 0.184 & 3 \\
\hline BNP Paribas & 0.000 & 1 & 0.000 & 1 & 0.000 & 1 & 0.007 & 1 & 69.880 & 2 & 0.069 & 3 \\
\hline Bureau Veritas & 0.504 & 4 & 0.000 & 2 & 0.000 & 2 & 0.507 & 4 & 31.765 & 1 & 0.000 & 1 \\
\hline Carrefour & 0.096 & 1 & 0.000 & 1 & 0.000 & 1 & 0.209 & 2 & 25.780 & 1 & 0.235 & 4 \\
\hline Crédit Agricole S.A. & 0.138 & 2 & 0.000 & 1 & 0.000 & 1 & 0.009 & 1 & 197.813 & 3 & 0.000 & 1 \\
\hline Danone & 0.137 & 2 & 2.510 & 3 & 0.012 & 3 & 0.564 & 4 & 158.836 & 3 & 0.229 & 4 \\
\hline Dassault Systèmes & 0.456 & 4 & 36.370 & 4 & 0.181 & 4 & 0.412 & 3 & 144.194 & 3 & 0.053 & 2 \\
\hline EADS & 0.216 & 3 & 22.378 & 4 & 0.056 & 4 & 0.153 & 2 & 95.595 & 2 & 0.189 & 3 \\
\hline EDF & 0.160 & 3 & 3.406 & 3 & 0.007 & 3 & 0.073 & 1 & 116.571 & 3 & 0.000 & 1 \\
\hline Essilor & 0.311 & 4 & 3.195 & 3 & 0.032 & 4 & 0.399 & 3 & 53.457 & 2 & 0.285 & 4 \\
\hline France Télécom S.A. & 0.238 & 4 & 0.000 & 2 & 0.000 & 2 & 0.435 & 3 & 229.851 & 4 & 0.000 & 1 \\
\hline Galp Energia & 0.018 & 1 & 0.000 & 1 & 0.000 & 1 & 0.124 & 2 & 233.412 & 4 & 0000 & 1 \\
\hline Heineken & 0.163 & 3 & 0.000 & 2 & 0.000 & 2 & 0.500 & 4 & 232.639 & 4 & 0.046 & 2 \\
\hline Iliad & 0.057 & 1 & 0.206 & 2 & 0.000 & 2 & 0.356 & 3 & 257.025 & 4 & 0.000 & 1 \\
\hline
\end{tabular}

\footnotetext{
${ }^{1}$ Capital employed $=$ total assets - current liabilities.
} 


\begin{tabular}{|c|c|c|c|c|c|c|c|c|c|c|c|c|}
\hline Firm & $\begin{array}{c}\text { LC/ } \\
\text { SALES }\end{array}$ & Score & $\begin{array}{l}\text { R\&D/ } \\
\text { NE }\end{array}$ & Score & $\begin{array}{c}\text { R\&D/ } \\
\text { SALES }\end{array}$ & Score & IA/TA & Score & IA/NE & Score & $\begin{array}{c}\text { M\&DE/ } \\
\text { Sales }\end{array}$ & Score \\
\hline ING Group & 0.160 & 3 & 0.000 & 2 & 0.000 & 2 & 0.002 & 1 & 31.15 & 1 & 0.016 & 2 \\
\hline Jéronimo Martins & 0.074 & 1 & 0.000 & 1 & 0.000 & 1 & 0.184 & 2 & 12.791 & 1 & 0.200 & 4 \\
\hline KBC & 0.168 & 3 & 0.000 & 2 & 0.000 & 2 & 0.005 & 1 & 25.975 & 1 & 0.048 & 2 \\
\hline Kering & 0.153 & 2 & 0.000 & 2 & 0.000 & 2 & 0.582 & 4 & 488.832 & 4 & 0.000 & 1 \\
\hline Lafarge & 0.153 & 2 & 0.000 & 1 & 0.000 & 1 & 0.334 & 3 & 199.015 & 4 & 0.033 & 2 \\
\hline Legrande & 0.008 & 1 & 5.955 & 3 & 0.044 & 4 & 0.645 & 4 & 129.348 & 3 & 0.024 & 2 \\
\hline L'Oréal & 0.197 & 3 & 10.883 & 4 & 0.035 & 4 & 0.316 & 3 & 125.33 & 3 & 0.188 & 3 \\
\hline LVMH & 0.171 & 3 & 0.649 & 2 & 0.002 & 3 & 0.394 & 3 & 181.63 & 3 & 0.151 & 3 \\
\hline Michelin & 0.250 & 4 & 5.797 & 3 & 0.029 & 4 & 0.041 & 1 & 7.614 & 1 & 0.038 & 2 \\
\hline Pernod Ricard & 0.144 & 2 & 0.000 & 1 & 0,000 & 1 & 0.657 & 4 & 948.219 & 4 & 0.133 & 3 \\
\hline Philips & 0.280 & 4 & 13.719 & 4 & 0.065 & 4 & 0.393 & 3 & 90.433 & 2 & 0.228 & 4 \\
\hline Publicis Groupe & 0.617 & 4 & 0.000 & 2 & 0.000 & 2 & 0.403 & 3 & 115.635 & 3 & 0,000 & 1 \\
\hline Renault & 0.141 & 2 & 8.852 & 4 & 0.027 & 4 & 0.046 & 1 & 27.399 & 1 & 0.300 & 4 \\
\hline Saint-Gobain S.A. & 0.196 & 3 & 2.360 & 3 & 0.010 & 3 & 0.305 & 2 & 73.946 & 2 & 0.168 & 3 \\
\hline Sanofi & 0.248 & 4 & 43.841 & 4 & 0.140 & 4 & 0.607 & 4 & 520.344 & 4 & 0.256 & 4 \\
\hline Schneider Electric & 0.000 & 1 & 6.943 & 4 & 0.044 & 4 & 0.506 & 4 & 114.336 & 2 & 0.327 & 4 \\
\hline Shell & 0.033 & 1 & 11.841 & 4 & 0.000 & 2 & 0.013 & 1 & 39.456 & 2 & 0.036 & 2 \\
\hline Société Générale & 0.133 & 2 & 0.000 & 1 & 0.000 & 1 & 0.006 & 1 & 45.264 & 2 & 0.000 & 1 \\
\hline Sodexo Alliance & 0.458 & 4 & 0.000 & 2 & 0.000 & 2 & 0.443 & 3 & 13.275 & 1 & 0.193 & 3 \\
\hline Technip & 0.271 & 4 & 1.882 & 3 & 0.008 & 3 & 0.299 & 2 & 92.243 & 2 & 0.059 & 3 \\
\hline Total & 0.039 & 1 & 8.288 & 4 & 0.004 & 3 & 0.076 & 2 & 132.385 & 3 & 0.000 & 1 \\
\hline Unilever & 0.123 & 2 & 5.831 & 3 & 0.020 & 3 & 0.478 & 3 & 126.267 & 3 & 0.266 & 4 \\
\hline $\mathrm{VINCl}$ & 0.264 & 4 & 0.000 & 2 & 0.000 & 2 & 0.498 & 4 & 0.000 & 1 & 0.000 & 1 \\
\hline Vivendi & 0.122 & 2 & 0.000 & 1 & 0.000 & 1 & 0.554 & 4 & 554.522 & 4 & 0.000 & 2 \\
\hline
\end{tabular}

Table 4. Financial/market performance scores (2012)

\begin{tabular}{|c|c|c|c|c|c|c|c|c|c|c|c|c|c|c|}
\hline Firm & MTBV & $\begin{array}{c}\text { Scor } \\
\mathrm{e}\end{array}$ & $\begin{array}{c}\text { MV/ } \\
\text { EBITDA }\end{array}$ & $\begin{array}{l}\text { Sc } \\
\text { ore }\end{array}$ & $\begin{array}{c}\text { MV/ } \\
\text { Sales }\end{array}$ & $\begin{array}{l}\text { Sc } \\
\text { ore }\end{array}$ & ROE & $\begin{array}{l}\text { Sc } \\
\text { ore }\end{array}$ & $\mathrm{ROA}$ & $\begin{array}{c}\text { Scor } \\
e\end{array}$ & $\begin{array}{l}\text { Cash } \\
\text { ROCE }\end{array}$ & $\begin{array}{l}\text { Sc } \\
\text { ore }\end{array}$ & $\begin{array}{l}\text { EBITDA/ } \\
\text { Sales }\end{array}$ & $\begin{array}{l}\text { Sco } \\
\text { re }\end{array}$ \\
\hline Ab_Inbev & 3.3871 & 4 & 8.4284 & 3 & 3.4292 & 4 & 0.1799 & 4 & 0.1127 & 3 & 0.2064 & 3 & 0.4069 & 4 \\
\hline Aegon & 0.4832 & 1 & 2.4866 & 1 & 0.3058 & 1 & 0.0671 & 2 & 0.0067 & 1 & 0.1052 & 1 & 0.1230 & 2 \\
\hline Ahold Kon. & 1.7972 & 3 & 5.4061 & 2 & 0.3281 & 1 & 0.1384 & 3 & 0.0812 & 3 & 0.2316 & 3 & 0.0607 & 1 \\
\hline Air Liquide & 2.9060 & 4 & 7.9614 & 3 & 1.9362 & 4 & 0.1576 & 3 & 0.1013 & 3 & 0.2330 & 3 & 0.2432 & 4 \\
\hline AkzoNobel & 1.7195 & 2 & -23.5604 & 1 & 0.7700 & 2 & -0.3147 & 1 & -0.0697 & 1 & -0.0489 & 1 & -0.0327 & 1 \\
\hline ArcelorMittal & 0.5150 & 1 & 27.5475 & 4 & 0.3095 & 1 & -0.0736 & 1 & -0.0359 & 1 & 0.0131 & 1 & 0.0112 & 1 \\
\hline ASML Holding & 4.9554 & 4 & 14.8326 & 4 & 4.2593 & 4 & 0.2819 & 4 & 0.1592 & 4 & 0.2817 & 4 & 0.2872 & 4 \\
\hline AXA & 0.7453 & 1 & 5.1650 & 2 & 0.3107 & 1 & 0.0971 & 2 & 0.0080 & 1 & 0.1155 & 1 & 0.0601 & 1 \\
\hline BNP Paribas & 0.6157 & 1 & 3.3376 & 1 & 0.6104 & 2 & 0.0730 & 2 & 0.0075 & 1 & 0.0856 & 1 & 0.1829 & 3 \\
\hline Bureau Veritas & 8.1915 & 4 & 13.9242 & 4 & 2.4025 & 4 & 0.2600 & 4 & 0.1368 & 4 & 0.2774 & 4 & 0.1725 & 3 \\
\hline Carrefour & 1.8325 & 3 & 5.2586 & 2 & 0.1749 & 1 & 0.1647 & 4 & 0.0241 & 1 & 0.1584 & 2 & 0.0333 & 1 \\
\hline Crédit Agricole & 0.3826 & 1 & 4.3685 & 2 & 0.3045 & 1 & -0.1629 & 1 & 0.0017 & 1 & 0.0153 & 1 & 0.0697 & 1 \\
\hline Danone & 2.6328 & 3 & 9.5698 & 4 & 1.5380 & 3 & 0.1372 & 3 & 0.0933 & 3 & 0.2016 & 3 & 0.1607 & 2 \\
\hline Dassault & 4.4363 & 4 & 15.9206 & 4 & 5.1720 & 4 & 0.1416 & 3 & 0.1489 & 4 & 0.2742 & 4 & 0.3249 & 4 \\
\hline EADS & 2.3443 & 3 & 5.7375 & 2 & 0.4320 & 1 & 0.1180 & 2 & 0.0251 & 1 & 0.3056 & 4 & 0.0753 & 1 \\
\hline EDF & 0.9996 & 2 & 1.8669 & 1 & 0.3554 & 1 & 0.1282 & 2 & 0.0284 & 1 & 0.1930 & 2 & 0.1904 & 3 \\
\hline Essilor & 4.4286 & 4 & 14.5850 & 4 & 3.2527 & 4 & 0.1594 & 4 & 0.1269 & 4 & 0.2655 & 4 & 0.2230 & 3 \\
\hline France & 0.9088 & 1 & 2.0762 & 1 & 0.5076 & 2 & 0.0337 & 1 & 0.0499 & 2 & 0.1893 & 2 & 0.2445 & 4 \\
\hline Galp Energia & 1.6791 & 2 & 8.4743 & 3 & 0.4864 & 2 & 0.0625 & 1 & 0.0471 & 2 & 0.1358 & 1 & 0.0574 & 1 \\
\hline Heineken & 2.4866 & 3 & 5.5521 & 2 & 1.5814 & 3 & 0.2522 & 4 & 0.1122 & 3 & 0.2277 & 3 & 0.2848 & 4 \\
\hline lliad & 4.2963 & 4 & 7.8074 & 3 & 2.3526 & 4 & 0.1097 & 2 & 0.0794 & 3 & 0.3294 & 4 & 0.3013 & 4 \\
\hline ING Group & 0.5501 & 1 & 5.4527 & 2 & 0.6360 & 2 & 0.0508 & 1 & 0.0036 & 1 & 0.0308 & 1 & 0.1166 & 2 \\
\hline Jéronimo & 7.5835 & 4 & 12.3312 & 4 & 0.8448 & 3 & 0.2975 & 4 & 0.1075 & 3 & 0.4180 & 4 & 0.0685 & 1 \\
\hline KBC & 0.6601 & 1 & 0.0000 & 1 & 0.6821 & 2 & -0.0260 & 1 & 0.0000 & 1 & 0.0000 & 1 & 0.0000 & 1 \\
\hline Kering & 1.5545 & 2 & 8.4583 & 3 & 1.8224 & 3 & 0.0918 & 2 & 0.0736 & 3 & 0.1456 & 2 & 0.2155 & 3 \\
\hline Lafarge & 0.8842 & 1 & 4.7268 & 2 & 0.8760 & 3 & 0.0276 & 1 & 0.0501 & 2 & 0.1088 & 1 & 0.1853 & 1 \\
\hline Legrande & 2.6359 & 3 & 8.2068 & 3 & 1.8796 & 3 & 0.1587 & 3 & 0.1291 & 4 & 0.2180 & 3 & 0.2290 & 4 \\
\hline L'Oréal & 3.0462 & 4 & 13.4204 & 4 & 2.8386 & 4 & 0.1370 & 3 & 0.1357 & 4 & 0.2265 & 3 & 0.2115 & 3 \\
\hline LVMH & 2.8689 & 3 & 10.2015 & 4 & 2.5076 & 4 & 0.1394 & 3 & 0.1201 & 4 & 0.2432 & 3 & 0.2458 & 4 \\
\hline Michelin & 1.5330 & 2 & 3.7163 & 2 & 0.6068 & 2 & 0.1836 & 4 & 0.1247 & 4 & 0.3339 & 4 & 0.1633 & 3 \\
\hline
\end{tabular}




\begin{tabular}{|l|c|c|c|c|c|c|c|c|c|c|c|c|c|c|}
\hline \multicolumn{1}{|c|}{ Firm } & MTBV & $\begin{array}{c}\text { Scor } \\
\mathrm{e}\end{array}$ & $\begin{array}{c}\mathrm{MV} / \\
\text { EBITDA }\end{array}$ & $\begin{array}{c}\text { Sc } \\
\text { ore }\end{array}$ & $\begin{array}{c}\text { MV/ } \\
\text { Sales }\end{array}$ & $\begin{array}{c}\text { Sc } \\
\text { ore }\end{array}$ & ROE & $\begin{array}{c}\text { Sc } \\
\text { ore }\end{array}$ & ROA & $\begin{array}{c}\text { Scor } \\
\text { e }\end{array}$ & $\begin{array}{c}\text { Cash } \\
\text { ROCE }\end{array}$ & $\begin{array}{c}\text { Sc } \\
\text { ore }\end{array}$ & $\begin{array}{c}\text { EBITDA/ } \\
\text { Sales }\end{array}$ & $\begin{array}{c}\text { Sco } \\
\text { re }\end{array}$ \\
\hline Pernod Ricard & 2.0647 & 3 & 10.9879 & 4 & 2.7152 & 4 & 0.1061 & 2 & 0.0700 & 2 & 0.1010 & 1 & 0.2471 & 4 \\
\hline Philips & 1.7093 & 2 & 8.0211 & 3 & 0.7682 & 2 & 0.0198 & 1 & 0.0391 & 2 & 0.1597 & 2 & 0.0958 & 2 \\
\hline Publicis & 2.0600 & 3 & 7.5241 & 3 & 1.4377 & 3 & 0.1598 & 4 & 0.0661 & 2 & 0.2364 & 3 & 0.1911 & 3 \\
\hline Renault & 0.4953 & 1 & 2.0877 & 1 & 0.2915 & 1 & 0.0729 & 2 & 0.0365 & 2 & 0.1868 & 2 & 0.1396 & 2 \\
\hline Saint-Gobain & 0.9812 & 2 & 4.4794 & 2 & 0.3961 & 1 & 0.0439 & 1 & 0.0410 & 2 & 0.1415 & 2 & 0.0884 & 1 \\
\hline Sanofi & 1.6489 & 2 & 8.6182 & 3 & 2.7053 & 4 & 0,0866 & 2 & 0.0664 & 2 & 0.1612 & 2 & 0.3139 & 4 \\
\hline Schneider & 1.8247 & 3 & 8.2790 & 3 & 1.2682 & 3 & 0.1106 & 2 & 0.0827 & 3 & 0.1591 & 2 & 0.1532 & 2 \\
\hline Shell & 0.7222 & 1 & 2.4009 & 1 & 0.2855 & 1 & 0.1440 & 3 & 0.1204 & 4 & 0.2596 & 4 & 0.1189 & 2 \\
\hline Société & 0.4440 & 1 & 2.9758 & 1 & 0.3092 & 1 & 0.0097 & 1 & 0.0037 & 3 & 0.0439 & 1 & 0.1039 & 2 \\
\hline Sodexo & 3.2561 & 4 & 7.3449 & 3 & 0.5417 & 2 & 0.1730 & 4 & 0.0799 & 1 & 0.2409 & 3 & 0.0738 & 1 \\
\hline Technip & 2.4511 & 3 & 9.4572 & 4 & 1.1954 & 3 & 0.1349 & 3 & 0.0747 & 3 & 0.1817 & 2 & 0.1264 & 2 \\
\hline Total & 1.2658 & 2 & 2.7062 & 1 & 0.5063 & 2 & 0.1467 & 3 & 0.1431 & 4 & 0.3583 & 4 & 0.1871 & 3 \\
\hline Unilever & 2.9470 & 4 & 5.3817 & 2 & 0.8704 & 3 & 0.2955 & 4 & 0.1563 & 4 & 0.3669 & 4 & 0.1617 & 2 \\
\hline VINCl & 1.5550 & 2 & 3.7158 & 1 & 0.5292 & 2 & 0.1437 & 3 & 0.0601 & 2 & 0.1889 & 2 & 0.1424 & 2 \\
\hline Vivendi & 1.2149 & 2 & 3.3806 & 1 & 0.7737 & 3 & 0.0089 & 1 & 0.0466 & 2 & 0.2134 & 3 & 0.2289 & 3 \\
\hline
\end{tabular}

Table 5. Summarized positioning results

\begin{tabular}{|c|c|c|c|c|c|c|c|c|c|c|}
\hline Firm & Quadrant & Quadrant & Quadrant & Quadrant & Quadrant & Quadrant & Quadrant & Quadrant & Quadrant & Quadrant \\
\hline $\mathrm{Ab}$ Inbev & Leader & Leader & Leader & Leader & Leader & Leader & Leader & Leader & Leader & Leader \\
\hline Aegon & $\mathrm{Bad}$ & $\mathrm{Bad}$ & $\mathrm{Bad}$ & $\mathrm{Bad}$ & $\mathrm{Bad}$ & $\mathrm{Bad}$ & $\mathrm{Bad}$ & $\mathrm{Bad}$ & $\mathrm{Bad}$ & $\mathrm{Bad}$ \\
\hline Ahold Kon. & $\mathrm{Bad}$ & $\mathrm{Bad}$ & $\mathrm{Bad}$ & $\mathrm{Bad}$ & $\mathrm{Bad}$ & Market- & $\mathrm{Bad}$ & $\mathrm{Bad}$ & $\mathrm{Bad}$ & $\mathrm{Bad}$ \\
\hline Air Liquide & Market- & Leader & Leader & Leader & Leader & Leader & Leader & Market- & Market- & Market- \\
\hline AkzoNobel & Leader & Leader & Leader & Leader & Visionary & Visionary & Visionary & Visionary & Visionary & Visionary \\
\hline ArcelorMittal & $\mathrm{Bad}$ & Market- & Market- & Bad & $\mathrm{Bad}$ & $\mathrm{Bad}$ & $\mathrm{Bad}$ & $\mathrm{Bad}$ & $\mathrm{Bad}$ & $\mathrm{Bad}$ \\
\hline ASML Holding & $\mathrm{Bad}$ & Market- & Market- & Market- & Market- & Market- & $\mathrm{Bad}$ & Market- & Market- & Market- \\
\hline AXA & Visionary & Visionary & $\mathrm{Bad}$ & Visionary & Visionary & Visionary & $\mathrm{Bad}$ & Visionary & $\mathrm{Bad}$ & $\mathrm{Bad}$ \\
\hline BNP Paribas & $\mathrm{Bad}$ & $\mathrm{Bad}$ & $\mathrm{Bad}$ & $\mathrm{Bad}$ & $\mathrm{Bad}$ & $\mathrm{Bad}$ & $\mathrm{Bad}$ & $\mathrm{Bad}$ & $\mathrm{Bad}$ & $\mathrm{Bad}$ \\
\hline Bureau Veritas & Market- & $\mathrm{Bad}$ & $\mathrm{Bad}$ & $\mathrm{Bad}$ & Market- & Market- & Market- & Market- & Market- & Market- \\
\hline Carrefour & Market- & Market- & $\mathrm{Bad}$ & $\mathrm{Bad}$ & $\mathrm{Bad}$ & $\mathrm{Bad}$ & $\mathrm{Bad}$ & $\mathrm{Bad}$ & $\mathrm{Bad}$ & $\mathrm{Bad}$ \\
\hline Crédit Agricole & $\mathrm{Bad}$ & $\mathrm{Bad}$ & $\mathrm{Bad}$ & $\mathrm{Bad}$ & $\mathrm{Bad}$ & $\mathrm{Bad}$ & $\mathrm{Bad}$ & $\mathrm{Bad}$ & $\mathrm{Bad}$ & $\mathrm{Bad}$ \\
\hline Danone & Leader & Leader & Leader & Leader & Leader & Leader & Leader & Leader & Leader & Leader \\
\hline Dassault & Market- & Leader & Leader & Leader & Leader & Leader & Leader & Leader & Leader & Leader \\
\hline EADS & Visionary & Visionary & Visionary & Visionary & Visionary & Visionary & Visionary & Visionary & Visionary & Visionary \\
\hline EDF & $\mathrm{Bad}$ & $\mathrm{Bad}$ & $\mathrm{Bad}$ & Market- & Market- & Market- & Leader & Visionary & $\mathrm{Bad}$ & Visionary \\
\hline Essilor & Leader & Leader & Market- & Market- & Market- & Leader & Leader & Leader & Leader & Leader \\
\hline France & Leader & Leader & Visionary & Visionary & Leader & Leader & Leader & Leader & Leader & Visionary \\
\hline Galp Energia & $\mathrm{Bad}$ & $\mathrm{Bad}$ & $\mathrm{Bad}$ & Market- & Market- & $\mathrm{Bad}$ & Market- & Market- & Market- & $\mathrm{Bad}$ \\
\hline Heineken & Market- & Market- & Market- & Market- & Market- & Visionary & Leader & Leader & Leader & Leader \\
\hline lliad & Leader & Leader & Market- & Market- & Market- & Market- & Market- & Leader & Leader & Leader \\
\hline ING Group & $\mathrm{Bad}$ & $\mathrm{Bad}$ & $\mathrm{Bad}$ & $\mathrm{Bad}$ & $\mathrm{Bad}$ & $\mathrm{Bad}$ & $\mathrm{Bad}$ & $\mathrm{Bad}$ & $\mathrm{Bad}$ & $\mathrm{Bad}$ \\
\hline Jéronimo & Market- & Market- & Market- & Market- & Market- & Market- & Market- & Market- & Market- & Market- \\
\hline KBC & $\mathrm{Bad}$ & $\mathrm{Bad}$ & $\mathrm{Bad}$ & $\mathrm{Bad}$ & $\mathrm{Bad}$ & $\mathrm{Bad}$ & $\mathrm{Bad}$ & $\mathrm{Bad}$ & $\mathrm{Bad}$ & $\mathrm{Bad}$ \\
\hline Kering & Visionary & Visionary & Visionary & Visionary & Visionary & Visionary & Visionary & Visionary & Visionary & Leader \\
\hline Lafarge & Leader & Visionary & Visionary & Visionary & Visionary & Visionary & Visionary & Visionary & Visionary & Visionary \\
\hline Legrande & Visionary & Visionary & Visionary & Leader & Leader & Leader & Leader & Leader & Leader & Leader \\
\hline L'Oréal & Leader & Leader & Leader & Leader & Leader & Leader & Leader & Leader & Leader & Leader \\
\hline LVMH & Leader & Leader & Leader & Leader & Leader & Leader & Leader & Leader & Market- & Market- \\
\hline Michelin & $\mathrm{Bad}$ & $\mathrm{Bad}$ & $\mathrm{Bad}$ & $\mathrm{Bad}$ & $\mathrm{Bad}$ & $\mathrm{Bad}$ & $\mathrm{Bad}$ & $\mathrm{Bad}$ & Market- & Market- \\
\hline Pernod Ricard & Leader & Leader & Leader & Leader & Leader & Leader & Leader & Leader & Leader & Leader \\
\hline Philips & Visionary & Visionary & Visionary & Visionary & Leader & Visionary & Visionary & Visionary & Visionary & Visionary \\
\hline Publicis & Leader & Market- & Market- & Market- & $\mathrm{Bad}$ & Market- & Market- & Market- & Market- & Market- \\
\hline Renault & $\mathrm{Bad}$ & Visionary & Visionary & Visionary & Visionary & Visionary & Visionary & Visionary & Visionary & Visionary \\
\hline Saint-Gobain & Visionary & Visionary & Visionary & Visionary & Visionary & Visionary & Visionary & Visionary & Visionary & Visionary \\
\hline Sanofi & Visionary & Visionary & Leader & Leader & Leader & Leader & Leader & Leader & Leader & Leader \\
\hline Schneider & Visionary & Visionary & Visionary & Visionary & Visionary & Leader & Leader & Leader & Visionary & Leader \\
\hline Shell & Market- & $\mathrm{Bad}$ & $\mathrm{Bad}$ & $\mathrm{Bad}$ & $\mathrm{Bad}$ & $\mathrm{Bad}$ & $\mathrm{Bad}$ & $\mathrm{Bad}$ & $\mathrm{Bad}$ & $\mathrm{Bad}$ \\
\hline Société & $\mathrm{Bad}$ & Market- & $\mathrm{Bad}$ & $\mathrm{Bad}$ & $\mathrm{Bad}$ & $\mathrm{Bad}$ & $\mathrm{Bad}$ & $\mathrm{Bad}$ & $\mathrm{Bad}$ & $\mathrm{Bad}$ \\
\hline Sodexo & $\mathrm{Bad}$ & $\mathrm{Bad}$ & $\mathrm{Bad}$ & $\mathrm{Bad}$ & $\mathrm{Bad}$ & Market- & $\mathrm{Bad}$ & $\mathrm{Bad}$ & Market- & Market- \\
\hline Technip & Visionary & Visionary & Visionary & Visionary & Visionary & Leader & Visionary & Leader & Leader & Leader \\
\hline Total & Market- & Market- & Market- & Market- & Market- & Market- & Market- & Market- & Market- & Market- \\
\hline Unilever & Leader & Leader & Leader & Leader & Leader & Leader & Leader & Leader & Leader & Leader \\
\hline VINCl & $\mathrm{Bad}$ & Market- & $\mathrm{Bad}$ & $\mathrm{Bad}$ & $\mathrm{Bad}$ & $\mathrm{Bad}$ & $\mathrm{Bad}$ & $\mathrm{Bad}$ & $\mathrm{Bad}$ & $\mathrm{Bad}$ \\
\hline Vivendi & $\overline{\mathrm{V}}$ & $\cdots$ & Leader & Leader & Visionary & Leader & Visionary & Leader & Leader & Visionary \\
\hline
\end{tabular}

